Biljana Trifunović*

UDK: $316.83: 2-453$

Jelena Šakotić-Kurbalija

DOI: $10.19090 / \mathrm{gff} .2020 .2 .115-130$

Tatjana Dajević

Originalni naučni rad

Filozofski fakultet

Univerzitet u Novom Sadu

\title{
SOCIODEMOGRAFSKI, INTRAPERSONALNI I INTERPERSONALNI KORELATI NEVERSTVA**
}

U cilju utvrđivanja sociodemografskih, intrapersonalnih i interpersonalnih korelata neverstva ispitan je 521 ispitanik (55.5\% muškog pola), starosti između 19 i 68 godina (AS $=33.32, S D=9.1$ ). Za procenu neverstva primenjena je Skala neverstva (Infidelity Scale: Drigotas, Safstorm \& Gentilila, 1999). Od intrapersonalnih varijabli, dimenzije partnerske afektivne vezanosti su ispitane skraćenom skalom ECR (Experiences in Close Relationships Inventory - ECR: Brennan, Clark, \& Shaver, 1998; modifikacija Kamenov i Jelić, 2003), a ljubavni stilovi su mereni Skalom ljubavnih stavova (Love Attitudes Scale - LAS: Hendrick, Hendrick, \& Dicke, 1998). U domenu interpersonalnih varijabli DAS skalom (Dyadic Adjustment Scale - DAS: Spanier, 1976) ispitane su dimenzije kvaliteta partnerskog odnosa, a potencijal za razvod je meren Indeksom bračne nestabilnosti (Martial Instability Index: Booth, Johnson, \& Edwards, 1983). Od sociodemografskih varijabli, od ispitanika su prikupljeni podaci o starosti, obrazovanju, radnom, materijalnom i bračnom statusu, dužini partnerskog odnosa i broju dece. Rezultati hijerarhijske višestruke regresione analize pokazuju da je skup intrapersonalnih i interpersonalnih varijabli, statistički značajno povezan sa neverstvom, ali je količina objašnjene varijanse relativno niska. Kao značajni prediktori neverstva izdvojeni su: dimenzija izbegavanja afektivne vezanosti i Ludus stil ljubavi iz domena intrapersonalnih varijabli, a od interpersonalnih varijabli: potencijal za razvod, konsenzus, zadovoljstvo brakom i afektivno-seksualna usaglašenost.

Ključne reči: partnerski odnosi, brak, kohabitacija, afektivna vezanost, ljubavni stilovi, bračni kvalitet, bračna nestabilnost, potencijal za razvod.

\footnotetext{
* jelenasakotickurbalija@ff.uns.ac.rs

** Istraživanje prikazano ovim radom predstavlja deo projekta „Efekti egzistencijalne nesigurnosti na pojedinca i porodicu u Srbiji“, koji finansira Ministarstvo prosvete, nauke i tehnološkog razvoja Republike Srbije (ON179022).
} 


\section{UVOD}

Mada je, istorijski posmatrano, pod neverstvom dugo podrazumevana samo seksualna prevara partnera, u savremenoj literaturi obično se razlikuju tri vrste neverstva u partnerskom odnosu:_emocionalno - koje se odnosi na emocionalne resurse poput ljubavi, vremena i pažnje koje jedan partner poklanja osobi van dijade, seksualno - koje je rezultat seksualne aktivnosti sa osobom koja nije primarni partner i kombinovani tip - koji uključuje i emocionalno i seksualno neverstvo i predstavlja najveću pretnju primarnoj dijadi (Glass \& Wright, 1985).

$\mathrm{Ne}$ postoji opšteprihvaćena definicija neverstva, a pojedini autori (npr. Hertlein et al., 2005) ističu da dodatni problem stvara to što dve osobe u istom partnerskom odnosu mogu imati značajno različita shvatanja o tome šta predstavlja neverstvo. U tom smislu je ono relativno subjektivno jer zavisi od eksplicitnih i implicitnih pravila (normi) postavljenih u partnerskom odnosu (Moller \& Vossler, 2014).

Drigotas i saradnici (Drigotas et al., 1999) istakli su da neverstvo, pored procene da je partner prekršio normu odnosa, u vezi sa prirodom partnerskih interakcija sa nekim drugim podrazumeva i činjenicu da kršenje ove norme izaziva seksualnu ljubomoru i rivalstvo. Tako se ponašanje koje predstavlja neverstvo može razlikovati od ponašanja koje je samo vandijadno, ali ne predstavlja kršenje normi odnosa u pogledu ekskluzivnosti. Autori (Drigotas et al., 1999) ističu da seksualna ljubomora predstavlja univerzalni proces, te da prevazilazi norme određene kulture ili norme bilo kog pojedinačnog odnosa.

Različiti autori kao najčešće razloge za neverstvo navode: seksualnost, emocionalno zadovoljstvo, društveni kontekst, stavove prema neverstvu i osvetu. Kada je u pitanju seksualnost, istraživanja ukazuju na potrebu za seksualnom raznolikošću i seksualnu nekompatibilnost sa partnerom. U slučaju emocionalnog zadovoljstva navodi se nisko bračno zadovoljstvo i potreba za novim emocionalnim zadovoljstvom. Oni koji su bili neverni često navode sledeće društvenokontekstualne faktore: prilika za neverstvo, bliskost sa osobom van dijade i fizička razdvojenost sa primarnim partnerom. Istraživanja u vezi sa stavovima prema neverstvu dosledno pokazuju da su osobe sa liberalnim seksualnim stavovima češće sklone da varaju svoje partnere, dok je i neverstvo iz osvete (odgovor na neverstvo partnera) često navođen razlog neverstva među bračnim parovima (pregled ovih istraživanja je dat u: Drigotas et al., 1999).

Pojedini autori navode da neverstvo u nekim slučajevima može biti način da se zadovolji potreba za autonomijom (kada se primarni odnos doživljava kao preterano ograničavajući), dok u drugim slučajevima (kada postoji doživljaj 
emocionalnog zanemarivanja unutar primarnog odnosa) može biti način da se zadovolji potreba za intimnošću. U oba slučaja neverstvo je povezano sa problemima u primarnom partnerskom odnosu (Allen \& Baucom, 2004). Iako neverstvu prethode problemi u partnerskom odnosu, nakon neverstva javljaju se novi, dodatni problemi i to kod oba partnera: smanjeno samopoštovanje, anksioznost, doživljaj krivice, depresija (Fincham \& May, 2017; Russell et al., 2013). Pored narušavanja mentalnog zdravlja, neverstvo je često povezano i sa nasiljem u porodici (Fincham \& May, 2017), te u gotovo svim kulturama ono predstavlja jedan od najčešćih razloga za prekid partnerskog odnosa ili razvod braka (Fish et al., 2012; Zare, 2011).

Iako su se istraživači najpre fokusirali na neverstvo koje uključuje seksualni odnos, sve je veće interesovanje za emocionalno, neseksualno neverstvo (Allen et al., 2005). Imajući u vidu da neverstvo može biti seksualno, emocionalno i kombinovano, te da u velikoj meri može doprineti disfunkcionalnosti partnerskog odnosa, istraživanjem prikazanim ovim radom ispitano je u kojoj meri različite sociodemografske, intrapersonalne i interpersonalne varijable doprinose predikciji neverstva u našoj sredini.

\section{METOD}

\section{Uzorak i procedura}

Istraživanje je sprovođeno tokom 2019. godine na teritoriji Republike Srbije. Jedan deo upitnika je ispitanicima zadavan u 'online' formi, deljenjem na društvenim mrežama, dok je drugi deo upitnika zadavan u 'papir-olovka' formi.

Uzorak je obuhvatio 521 ispitanika ( $55.5 \%$ muškog pola), starosti između 19 i 68 godina $(A S=33.32, S D=9.1)$, koji žive u formalnom $(53.4 \%)$ ili neformalnom braku (46.6\%), između mesec dana i 42 godine $(A S=6.89, S D=$ 8.66). Veći broj ispitanika obuhvaćenih ovim istraživanjem nema decu (57\%).

Najveći broj ispitanika ima visoku stručnu spremu (56.4\%), manji broj njih ima srednju stručnu spremu (29.8\%), i višu stručnu spremu $(10.7 \%)$, dok je istraživanjem obuhvaćen najmanji broj doktora nauka (2.5\%), kao i ispitanika sa nižom stručnom spremom $(0.6 \%)$.

Istraživanjem je obuhvaćen najveći deo ispitanika zaposlenih 'za stalno' (47.8\%), odnosno na određeno vreme, honorarno (24.6\%), manji broj njih je trenutno nezaposlen i traži posao (16.3\%). Najmanji broj ispitanika je (su)vlasnik firme (6.9\%), izjašnjava se kao domaćica (2.7\%) ili je u invalidskoj penziji (1.7\%). 
Najveći broj ispitanika procenjuje svoj materijalni status kao prosečan (34.4\%) i nešto iznadprosečan (34.0\%), manji broj njih kao znatno iznadprosečan $(15 \%)$ i nešto ispodprosečan (11.3\%), dok najmanji broj ispitanika svoj materijalni status procenjuje kao znatno ispodprosečan $(5.4 \%)$.

\section{Instrumenti}

Skala neverstva (Infidelity Scale: Drigotas et al., 1999) služi za procenu emocionalnog, seksualnog i kompozitnog neverstva $(\alpha=.94)$. Sastoji se iz 11 stavki, pri čemu je 10 stavki sa devetostepenom skalom Likertovog tipa za odgovaranje, dok za pitanje "Ko je napravio prvi korak?" ispitanik treba da odabere jednu od ponuđenih opcija: druga osoba, oboje, ja. Uputstvom (koje ističe da je ljudski biti svestan toga da nas privlači i neko drugi, pored trenutnog partnera) normalizuje se iskustvo neverstva, te se očekuje da će ispitanici iskrenije davati odgovore.

Skala za procenjivanje bliskih veza (Experiences in Close Relationships Inventory - ECR: Brennan, et al., 1998; modifikacija Kamenov i Jelić, 2003). Za identifikovanje dimenzija partnerske afektivne vezanosti primenjena je skraćena verzija skale od 18 stavki (Kamenov i Jelić, 2003). Instrument je zasnovan na dvodimenzionalnom modelu individualnih razlika u afektivnom vezivanju odraslih. Parne stavke čine skalu anksioznosti $(\alpha=.80)$, a neparne skalu izbegavanja $(\alpha=$ $.83)$.

Skala ljubavnih stavova (Love Attitudes Scale - LAS: Hendrick et al., 1998) služi za merenje stavova o ljubavi i razvijena je na osnovu Lijeve tipologije ljubavnih stilova (Lee, 1973). Upitnik se sastoji od 42 stavke, sa petostepenom skalom Likertovog tipa za odgovaranje, kojima se procenjuje šest stilova ljubavi: eros (strasna ljubav; $\alpha=.78$ ), ludus (ljubav kao igra; $\alpha=.73$ ), storge (prijateljska ljubav; $\alpha=.82$ ), pragma (pragmatična ljubav; $\alpha=.77$ ), manija (posesivna ljubav, $\alpha$ $=.81$ ) i agape (nesebična ljubav; $\alpha=.88$ ).

Skala prilagođenosti u bračnom odnosu (Dyadic Adjustment Scale - DAS: Spanier, 1976) namenjena je proceni kvaliteta bračnog odnosa i čine je 32 stavke. Pored ukupnog skora $(\alpha=.94)$, omogućava i izračunavanje skorova na sledećim skalama: 1. konsenzus $(\alpha=.87)$ - meri stepen slaganja partnera u svakodnevnom funkcionisanju; 2. zadovoljstvo brakom $(\alpha=.85)$ - obuhvata opšte zadovoljstvo brakom, poverenje u partnera, učestalost bračnih konflikta, stepen bračne tenzije, doživljaj međusobne netrpeljivosti i lični odnos prema budućnosti braka; 3 . afektivno-seksualna usaglašenost $(\alpha=.67)$ - meri stepen usaglašenosti partnera $u$ 
ispoljavanju emocija i seksualnim odnosima; 4. kohezivnost $(\alpha=.79)$-meri stepen bliskosti i kvalitet komunikacije među partnerima.

Indeks bračne nestabilnosti (Martial Instability Index: Booth et al., 1983) korišćen je za procenu potencijala za razvod. Instrument uključuje sledeće stavke na koje se odgovara potvrdno ili odrično: prisustvo razmišljanja o tome da je brak u krizi, prisustvo razmišljanja o razvodu braka, postojanje razgovora sa prijateljima o razvodu, postojanje razgovora sa bračnim partnerom o razvodu braka i postojanje razgovora sa bračnim partnerom o odlasku kod advokata. U ovom istraživanju Cronbahov alfa-koeficijent pouzdanosti skale iznosi .78.

\section{REZULTATI}

U Tabeli 1 prikazani su deskriptivni parametri varijabli korišćenih u istraživanju. Prema blažem kriterijumu ( $\square 1.5)$, vrednosti skjunisa i kurtozisa se mogu smatrati prihvatljivim za sve korišćene varijable (Finney \& DiStefano, 2006).

Tabela 1: Deskriptivni parametri varijabli korišćenih u istraživanju

\begin{tabular}{lcccccc}
\hline Varijabla & Min & Max & $A S$ & $S D$ & $S k$ & $K$ \\
\hline neverstvo & 0 & 81 & 40.70 & 23.49 & -0.04 & -1.06 \\
anksioznost & 9 & 62 & 22.66 & 9.78 & 0.84 & 0.53 \\
izbegavanje & 9 & 51 & 20.54 & 9.02 & 0.73 & -0.12 \\
eros & 9 & 35 & 28.53 & 5.17 & -0.72 & -0.11 \\
ludus & 7 & 35 & 14.73 & 5.27 & 0.70 & 0.24 \\
storge & 7 & 35 & 22.24 & 5.22 & 0.14 & -0.21 \\
pragma & 7 & 35 & 18.00 & 5.83 & 0.24 & -0.34 \\
mania & 7 & 35 & 18.11 & 5.85 & 0.35 & -0.34 \\
agape & 10 & 35 & 25.37 & 6.14 & -0.35 & -0.56 \\
konsenzus & 9 & 65 & 48.56 & 9.50 & -1.02 & 1.08 \\
ekspresivnost & 0 & 12 & 8.77 & 2.42 & -0.71 & 0.42 \\
zadovoljstvo & 2 & 50 & 37.28 & 7.54 & -0.91 & 0.76 \\
kohezivnost & 1 & 24 & 17.16 & 4.06 & -0.91 & 0.89 \\
potencijal za razvod & 0 & 5 & 1.59 & 1.48 & 0.60 & -0.84 \\
\hline Napomena: Sk-skjun & $\mathrm{K}$ & $-\mathrm{k}$ & & & &
\end{tabular}

Napomena: Sk - skjunis; K - kurtozis

U Tabeli 2 prikazane su interkorelacije prediktorskih varijabli od interesa. Kao što se može videti interkorelacije varijabli ne upućuju na postojanje multikolinearnosti među prediktorskim varijablama ( $r \square .70$ ), te su sve varijable uključene kao prediktori u regresioni model. 
Tabela 2: Interkorelacije varijabli

\begin{tabular}{|c|c|c|c|c|c|c|c|c|c|c|c|c|c|}
\hline Varijable & 1 & 2 & 3 & 4 & 5 & 6 & 7 & 8 & 9 & 10 & 11 & 12 & 13 \\
\hline \multicolumn{14}{|l|}{ 1. neverstvo } \\
\hline 2.anksioznost & $.13 * *$ & & & & & & & & & & & & \\
\hline 3.izbegavanje & $.27 * *$ & $.36 * *$ & & & & & & & & & & & \\
\hline 4.eros & $-.21 * *$ & $-.20 * *$ & $-.38 * *$ & & & & & & & & & & \\
\hline 5.ludus & $.28 * *$ & $.29 * *$ & $.43^{* *}$ & $-.24 * *$ & & & & & & & & & \\
\hline 6.storge & .07 & $.09 *$ & -.01 & $-.13 * *$ & $.12 * *$ & & & & & & & & \\
\hline 7.pragma & $.16^{* *}$ & $.21 * *$ & $.23 * *$ & $-.20 * *$ & $.33 * *$ & $.20 * *$ & & & & & & & \\
\hline 8.mania & $.11^{* *}$ & $.54 * *$ & $.14^{* *}$ & -.01 & $.32 * *$ & $.09 *$ & $.21 * *$ & & & & & & \\
\hline 9.agape & $-.13 * *$ & -.01 & $-.24 * *$ & $.41 * *$ & $-.11^{*}$ & $.17 * *$ & $-.11 *$ & $.15^{* *}$ & & & & & \\
\hline 10.konsenzus & $-.21 * *$ & $-.29 * *$ & $-.47 * *$ & $.51 * *$ & $-.34 * *$ & -.06 & $-.16 * *$ & * $-.14 * *$ & *.27** & & & & \\
\hline 11.ekspresivnost & $-.32 * *$ & $-.32 * *$ & $-.40 * *$ & $.52 * *$ & $-.22 * *$ & -.08 & $-.11 *$ & $-.16^{* *}$ & *.21** & $.65^{* *}$ & & & \\
\hline 12.zadovoljstvo & $-.35 * *$ & $-.29 * *$ & $-.46 * *$ & $.53 * *$ & -.34 & -.04 & $-.16^{* *}$ & $-16^{* *}$ & $.31 * *$ & $.68 * *$ & $.66^{* *}$ & & \\
\hline 13.kohezivnost & $-.13 * *$ & $-.18 * *$ & $-.39 * *$ & $.48 * *$ & $-.26 * *$ & -.04 & $-.11 * *$ & $k^{k}-.07$ & $.26^{* *}$ & $.59 * *$ & $.47 * *$ & $.55 * *$ & \\
\hline $\begin{array}{l}\text { 14.bračna } \\
\text { nestabilnost }\end{array}$ & $.32 * *$ & $.20 * *$ & $.24 * *$ & $-.35 * *$ & $.18^{* *}$ & -.04 & .06 & $.15 * *$ & $-.28 * *$ & -.47 & $-.49 * *$ & $-.59 * *$ & $-.30 * *$ \\
\hline
\end{tabular}

U cilju utvrđivanja u kojoj meri sociodemografske, intrapersonalne $\mathrm{i}$ interpersonalne varijable doprinose predikciji neverstva primenjena je hijerarhijska višestruka regresiona analiza. U prvom koraku analize prediktorske varijable su bile sociodemografske varijable kako bi se utvrdio njihov početni uticaj. U drugom koraku u analizu su uvrštene intrapersonalne varijable - dimenzije afektivne vezanosti i stilovi ljubavi. U trećem koraku u analizu su uvrštene i interpersonalne varijable - dimenzije kvaliteta bračnog odnosa i bračna nestabilnost. Iz analize je isključena varijabla vezana za dužinu zajedničkog života zbog visoke korelacije sa starošću ispitanika $(r=.89)$.

Rezultati pokazuju da skup analiziranih sociodemografskih varijabli nije statistički značajno povezan sa sklonošću ka neverstvu, dok je skup intrapersonalnih i interpersonalnih varijabli statistički značajno povezan sa sklonošću ka neverstvu, ali je količina objašnjene varijanse relativno niska. Koeficijenti multiple korelacije iznose:

- $\quad$ za skup sociodemografskih varijabli $R=.11(F(7,490)=0.80 ; p>.001)$, dok je $R^{2}=.01$ (1\% zajedničke varijanse);

- $\quad$ posle uvođenja intrapersonalnih varijabli $R=.35(F(15,482)=4.59 ; p<$ $.001)$, dok je $R^{2}=.12$ (12\% zajedničke varijanse);

- $\quad$ posle uvođenja interpersonalnih varijabli $R=.46(F(20,477)=6.38 ; p<$ $.001)$, dok je $R^{2}=.21$ (21\% zajedničke varijanse). 
U Tabeli 3 prikazani su regresioni parametri za prediktorske varijable. Kao što se može videti iz tabele, značajan doprinos predikciji neverstva ostvaruje dimenzija izbegavanja afektivne vezanosti i ludus stil ljubavi iz domena intrapersonalnih varijabli, kao i skoro sve uvrštene interpersonalne varijable bračna nestabilnost i sve dimenzije bračnog kvaliteta izuzev kohezivnosti.

Tabela 3: Rezultati hijerarhijske višestruke regresione analize

\begin{tabular}{|c|c|c|c|c|c|c|c|c|c|}
\hline \multirow{2}{*}{ Prediktor } & \multicolumn{3}{|c|}{ Model 1} & \multicolumn{3}{|c|}{ Model 2} & \multicolumn{3}{|c|}{ Model 3} \\
\hline & B & SE B & $\beta$ & B & SE B & B & B & SE B & $\beta$ \\
\hline pol & -.38 & 2.21 & -.01 & -.17 & 2.36 & -.00 & -.64 & 2.29 & -.01 \\
\hline starost & .04 & .14 & .01 & -.16 & .14 & -.06 & -.14 & .13 & -.06 \\
\hline obrazovanje & .25 & 1.19 & .01 & .36 & 1.16 & .01 & .61 & 1.13 & .02 \\
\hline radni status & 1.85 & 1.06 & .08 & 1.62 & 1.01 & .07 & 1.23 & .97 & .06 \\
\hline $\begin{array}{l}\text { materijalni } \\
\text { status }\end{array}$ & -.04 & 1.03 & -.00 & .14 & .99 & .01 & .27 & .95 & .01 \\
\hline bračni status & 3.76 & 2.93 & .08 & 3.10 & 2.81 & .07 & .83 & 2.72 & .02 \\
\hline deca & -3.29 & 3.10 & -.07 & -1.57 & 2.96 & -.03 & -.32 & 2.84 & -.01 \\
\hline anksioznost & & & & -0.8 & .13 & -.03 & -.16 & .13 & -.07 \\
\hline izbegavanje & & & & .43 & .14 & $.16^{*}$ & .34 & .14 & $.13^{*}$ \\
\hline eros & & & & -.32 & .24 & -07 & .16 & .26 & .03 \\
\hline ludus & & & & .79 & .24 & $.18^{*}$ & .77 & .23 & $.17^{*}$ \\
\hline storge & & & & .07 & .21 & .01 & .12 & .20 & .03 \\
\hline pragma & & & & .16 & .19 & .04 & .25 & .19 & .06 \\
\hline mania & & & & .16 & .22 & .04 & .01 & .21 & .00 \\
\hline agape & & & & -.18 & .21 & -.05 & -.08 & .20 & -.02 \\
\hline konsenzus & & & & & & & .38 & .16 & $.15^{*}$ \\
\hline ekspresivnost & & & & & & & -1.83 & .59 & $-.19^{*}$ \\
\hline zadovoljstvo & & & & & & & -.58 & .21 & $-.19^{*}$ \\
\hline kohezivnost & & & & & & & .55 & .31 & .09 \\
\hline $\begin{array}{l}\text { potencijal za } \\
\text { razvod }\end{array}$ & & & & & & & 2.58 & .87 & $.16^{*}$ \\
\hline
\end{tabular}

Napomena: ${ }^{*} p<.01$

\section{DISKUSIJA}

Rezultati sprovedenog istraživanja ukazuju na mogućnost predikcije neverstva na osnovu intrapersonalnih i interpersonalnih varijabli, potvrđujući tako rezultate većeg broja ranije sprovedenih studija (Gibson et al., 2016; Mark et al., 2011; McAnulty \& Brineman, 2007). Količina objašnjene varijanse je relativno 
niska, što ukazuje na postojanje drugih faktora relevantnih za predikciju neverstva, koji nisu bili obuhvaćeni ovim istraživanjem, poput osobina ličnosti (Barta \& Kiene, 2005; Shackelford et al., 2008) iz domena intrapersonalnih varijabli ili stepena posvećenosti (Mattingly et al., 2011) i iz domena interpersonalnih varijabli, koji su izdvojeni kao značajni prediktori neverstva u prethodnim istraživanjima.

Za razliku od nekih prethodnih istraživanja u kojima su različite sociodemografske varijable ostvarile značajan doprinos predikciji neverstva (Atkins et al., 2001; Allen et al., 2005; Mark et al., 2011), u ovom istraživanju sociodemografski faktori nisu izdvojeni kao značajni prediktori. Iako ranije sprovedena istraživanja ukazuju na to da su muškarci skloniji neverstvu u odnosu na žene (Wiederman, 1997), novija istraživanja sugerišu da se polne razlike u neverstvu smanjuju (Burdette et al., 2007; Fincham \& May, 2017), što potvrđuju i rezultati ove studije. Kada se u razmatranje uzmu i vandijadna ponašanja, sem seksualnog odnosa (poput emocionalne povezanosti, ljubljenja i sl.) žene izveštavaju o činu neverstva u istom stepenu kao muškarci (Allen et al., 2005), te su rezultati dobijeni u ovom istraživanju donekle očekivani, s obzirom na ispitivano kompozitno neverstvo, odnosno seksualno i emocionalno neverstvo. Pored toga, pojedini autori (npr. Abzug, 2016) manje izražene polne razlike pripisuju i većem profesionalnom angažmanu žena, koji stvara veću finansijsku nezavisnost i veće prilike za neverstvo.

Pored pola u literaturi se prepoznaje značaj starosti, obrazovanja, radnog i materijalnog statusa u predikciji neverstva (Atkins et al., 2001; Allen et al., 2005; Treas \& Giesen, 2000). Međutim, dosadašnji rezultati studija nisu bili konzistentni. $S$ jedne strane, neke studije ukazuju na to da mlađe osobe sa višim obrazovanjem i radno angažovane imaju veću verovatnoću angažovanja u vandijadnim ponašanjima (Mark et al., 2011), dok, sa druge strane, neka istraživanja govore o većoj prevalenciji neverstva kod starijih (Atkins et al., 2001), i manje obrazovanih ispitanika (Whisman \& Snyder, 2007). Pored toga, rezultati ove i pojedinih prethodnih studija ne nalaze značajan doprinos pomenutih demografskih faktora (Maddox Shaw et al., 2013; Træen et al., 2007). Rezultati dobijeni u ovoj studiji mogu biti objašnjeni i karakteristikama samog uzorka, s obzirom na to da su ovim istraživanjem obuhvaćeni najvećim delom visoko obrazovani, radno angažovani ispitanici ranog odraslog doba. Uzimajući u obzir i nekonzistentne rezultate dosadašnjih studija u pogledu značajnosti sociodemografskih faktora za predikciju neverstva, postoji mogućnost da je odnos ovih varijabli posredovan drugim faktorima. Ovo objašnjenje se potencijalno može primeniti i prilikom razmatranja izostanka značajnog doprinosa bračnog statusa predikciji neverstva, pri čemu na 
dati odnos može uticati posvećenost. Pojedina istraživanja ukazuju na to da osobe u braku pokazuju niži stepen neverstva (Treas \& Giesen, 2000), jer su više investirane $\mathrm{u}$ relaciju i pokazuju viši nivo posvećenosti u odnosu na osobe $\mathrm{u}$ kohabitaciji (Preveti \& Amato, 2004).

Na osnovu rezultata ove studije može se, takođe, zaključiti da su zajedničke karakteristike koje dele stil izbegavanja afektivne vezanosti i ludus ljubavni stil u vezi sa povećanom tendencijom $\mathrm{ka}$ neverstvu. Individue sa pomenutim karakteristikama odlikuje smanjena emocionalna investiranost, autonomija, sveukupno izbegavanje intimnosti (Bartholomew, 1990), povećana potreba za uzbuđenjima i pristup ljubavi koji može podrazumevati više partnera istovremeno (Lee, 1973). Nelagodnost uspostavljanja i održavanja bliskosti i intimnosti sa partnerom ostvaruje direktne posledice na to koliko su individue zainteresovane za alternativne partnere, na stavove prema varanju partnera, njihovu posvećenost, a samim tim i na neverstvo (DeWall et al., 2011). Dakle, neverstvo se može koristiti kao metod distanciranja od partnera, postizanja veće autonomije (Allen \& Baucom, 2004) i uzbuđenja u relaciji.

Sa druge strane, individue koje karakteriše želja za bliskošću i intimnošću sa partnerom ne ispoljavaju veće interesovanje za alternativne partnere, ne izveštavaju o pozitivnim stavovima prema varanju partnera, niti u većem stepenu izveštavaju o neverstvu (DeWall et al., 2011), jer ova ponašanja mogu ugroziti mogućnost ostvarivanja bliske i posvećene relacije sa primarnim partnerom. Iako ove individue mogu u većem stepenu ispoljavati neverstvo kada se osećaju usamljeno i zanemareno, ili su u konfliktu sa partnerom (Fish et al., 2012), odnosno, kada njihove potrebe za intimnošću nisu zadovoljene, ove osobe mogu primeniti i druge metode da zadovolje svoje potrebe; neverstvo može predstavljati samo jednu vrstu ponašanja za zadovoljenje pomenutih potreba.

Interpersonalne varijable takođe ostvaruju značajan doprinos predikciji neverstva, pri čemu su skoro sve dimenzije doživljaja kvaliteta bračnog odnosa izdvojene kao značajni prediktori. Dobijeni rezultati su saglasni sa Thompsonovim (Thompson, 1983) “deficitarnim modelom” objašnjenja neverstva koji polazi od pretpostavke da deficiti u primarnoj relaciji igraju centralnu ulogu u precipitiranju i održavanju neverstva. Individue koje ne mogu da zadovolje svoje potrebe ili očekivanja od partnerskog odnosa $u$ primarnoj relaciji, koje su $u$ nezadovoljavajućim relacijama, odnosno koje karakteriše neslaganje sa partnerima $\mathrm{u}$ svakodnevnom funkcionisanju, te neusaglašenost $\mathrm{u}$ ispoljavanju emocija $\mathrm{i}$ seksualnim odnosima, iskazuju veću sklonost ka neverstvu. Generalno, bračno nezadovoljstvo i neusaglašenost $u$ ispoljavanju emocija i seksualnim odnosima 
ostvaruju najveći doprinos predikciji neverstva. Bračno zadovoljstvo se dosledno dovodi u vezu sa negativnijim stavovima prema neverstvu (Larson, 2014), te manje izraženom neverstvu (Atkins et al., 2001), pri čemu se pretpostavlja da su individue koje su zadovoljne svojim bračnim odnosom posvećenije i verne partneru. Dodatno, reciprocitet $i$ kompatibilnost $u$ emocionalnom ispoljavanju, a naročito $u$ seksualnim odnosima, može učvrstiti partnerski odnos (Turliuc \& Scutaru, 2013), te smanjiti verovatnoću formiranja seksualnog i/ili emocionalnog odnosa sa osobama van primarne romantične relacije.

Veću sklonost ka neverstvu pokazuju i individue koje izveštavaju o većem potencijalu za razvod. Pretpostavlja se da, kada individue počnu da razmišljaju ili razgovaraju o mogućnosti razvoda, razmišljaju i o traženju drugog emotivnog i/ili seksualnog partnera. Ovo ponašanje može odražavati želju individue da pronađe ili započne odnos sa drugim partnerom usled anticipiranja završetka bračnog odnosa. Međutim, bitno je istaći da je odnos neverstva i potencijala za razvod, kao i ostalih ispitivanih interpersonalnih varijabli, najverovatnije dvosmeran. Naime, iako generalno lošiji kvalitet bračnog odnosa i veći potencijal za razvod doprinose pojavi neverstva, isto tako neverstvo, bilo emocionalno, seksualno ili kombinovano, negativno deluje na brak - smanjuje kvalitet bračnog odnosa i povećava bračnu nestabilnost.

Prilikom razmatranja dobijenih rezultata neophodno je uzeti u obzir i ograničenja sprovedene studije. Iako istraživanja ukazuju na veliku učestalost neverstva (Allen et al., 2005; Atkins et al., 2001; Treas \& Giesen, 2000), ponašanja koja uključuju ostvarivanje emocionalnog i/ili fizičkog odnosa sa osobom izvan primarne relacije generalno se smatraju neprihvatljivim. Stoga postoji mogućnost da ispitanici nisu bili potpuno iskreni prilikom izveštavanja o svojim iskustvima, iako su odgovarali anonimno. Pored toga, istraživanjem su najvećim delom obuhvaćeni ispitanici ranog odraslog doba, koji su visokoobrazovani, radno angažovani, prosečnog i iznadprosečnog materijalnog statusa, što je moglo doprineti izostanku značajnog doprinosa sociodemografskih varijabli predikciji neverstva, i čime je smanjena mogućnost generalizacije dobijenih rezultata. Takođe, važno ograničenje koje se mora uzeti u obzir prilikom razmatranja dobijenih rezultata jeste kros-sekcionalna priroda samog istraživanja, koja onemogućava izvođenje zaključaka o uzročno-posledičnoj vezi ispitivanih konstrukata. Postavljanje prediktivnog modela i interpretiranje rezultata dobijenih u ovom istraživanju je, na osnovu rezultata prethodnih istraživanja, rukovođeno pretpostavkom da uključeni sociodemografski, intrapersonalni i interpersonalni faktori doprinose formiranju emocionalnih i/ili seksualnih odnosa sa osobom izvan 
primarnog partnerskog odnosa. Međutim, kao što je već istaknuto, postoji velika verovatnoća da je neverstvo dvosmerno povezano sa ispitivanim varijablama, naročito sa onim iz interpersonalnog domena, što je potrebno dodatno proveriti u budućim longitudinalnim studijama.

U istraživanjima se dosledno identifikuju negativni efekti neverstva, pa čak i sumnje na isto (Schackelford et al., 2000; Vandello \& Cohen, 2003), uključujući štetne efekte na mentalno zdravlje oba parnera. Pri tome kod prevarenih partnera česte su emocionalne reakcije poput besa, depresije, doživljaja poniženosti (Cano \& O'Leary, 2000), dok partner koji je počinio neverstvo takođe često doživljava osećanja besa i depresije ili stida, što neverstvo čini vrlo stresnim iskustvom za par kao celinu, predstavlja ozbiljnu pretnju za dalje interakcije (Gordon et al., 2005) i ukazuje na sve veći značaj ispitivanja ovog fenomena. Zato, i pored pobrojanih ograničenja, rezultati sprovedene studije daju doprinos postojećoj literaturi, pre svega razmatrajući relativni značaj sociodemografskih, intrapersonalnih i interpersonalnih faktora u predikciji neverstva, budući da je većina istraživanja ispitivala njihove pojedinačne doprinose. Predisponirajući faktori, poput faktora ispitanih u ovoj studiji, igraju važnu ulogu i u identifikovanju individua i relacija pod povećanim rizikom za neverstvo, što može pomoći u njenom preveniranju i tretiranju, prilagođavanjem sadržaja savetodavnih i terapijskih bračnih programa (Markman, 2005).

Biljana Trifunović, Jelena Šakotić-Kurbalija, Tatjana Dajević

\section{DEMOGRAPHIC, INTRAPERSONAL AND INTERPERSONAL CORRELATES OF INFIDELITY}

\section{Summary}

In order to determine sociodemographic, intrapersonal and interpersonal correlates of infidelity, 521 respondents (55.5\% man), aged between 19 and 68 years $(M=33.32, S D=$ 9.1), living in formal (53.4\%) or informal marriage (46.6\%), between one month and 42 years $(M=6.89, S D=8.66)$ completed a series of questionnaires, including Infidelity Scale (Drigotas, Safstorm \& Gentilila, 1999) for assessment of infidelity. In the domain of intrapersonal variables, the attachment dimensions were examined using the abbreviated form of Experiences in Close Relationships Inventory (ECR: Brennan, Clark, \& Shaver, 1998; modification Kamenov \& Jelić, 2003), as well as the love attitudes assessed by the Love Attitudes Scale (LAS: Hendrick, Hendrick, \& Dicke, 1998). In the domain of interpersonal variables, the dimensions of marital quality were examined using the Dyadic Adjustment Scale (DAS: Spanier, 1976), as well as the potential for divorce assessed by the Martial Instability Index (Booth, Johnson \& Edwards, 1983). The respodents also answered 
questions about age, education, employment, income, marital status, relationship duration, as well as the number of children. The results of hierarchical multiple regression analysis show that the sets of intrapersonal and interpersonal variables are statistically significantly associated with infidelity, but the amount of explained variance is relatively low, indicating the existence of other factors relevant to prediction of infidelity which were not included in this study. Significant predictors of infidelity are attachment avoidance and Ludus style of love in the domain of intrapersonal variables, as well as almost all included interpersonal variables - marital instability and dimensions of marital quality Dyadic Consensus, Dyadic Satisfaction, and Affectional Expression. The study results contribute to the existing literature primarily by considering the relative contribution of sociodemographic, intrapersonal and interpersonal factors to the prediction of infidelity since most studies have examined their individual contributions. Predisposing factors, such as those examined in this study, also play an important role in identifying individuals and relationships at increased risk for infidelity which can help in prevention and treatment of infidelity.

Key words: infidelity, marriage, attachment, love attitudes, marital quality, potential for divorce

\section{LITERATURA}

Abzug, R. (2016). Extramarital affairs as occupational hazard: A structural, ethical (cultural) model of opportunity. Sexualities, 19(1-2), 25-45. doi: $10.1177 / 1363460715583586$

Allen, E. S., \& Baucom, D. H. (2004). Adult attachment and patterns of extradyadic involvement. Family Process,43(4), 467-488. doi: 10.1111/j.15455300.2004.00035.x

Allen, E. S., Atkins, D. C., Baucom, D. H., Snyder, D. K., Gordon, K. C., \& Glass, S. P. (2005). Intrapersonal, interpersonal, and contextual factors in engaging in and responding to extramarital involvement. Clinical Psychology: Science and Practice, 12, 101-130. doi: 10.1093/clipsy.bpi014

Atkins, D. C., Baucom, D. H., \& Jacobson, N. S. (2001). Understanding Infidelity: Correlates in a National Random Sample. Journal of Family Psychology, 15, 735-749.doi: 10.1037/0893-3200.15.4.735

Barta, W. D., \& Kiene, S. M. (2005). Motivations for infidelity in heterosexual dating couples: The roles of gender, personality differences, and sociosexual orientation. Journal of Social and Personal Relationships, 22(3), 339-360. doi: 10.1177/0265407505052440

Bartholomew, K. (1990). Avoidance of intimacy: an attachment perspective. Journal of Social and Personal Relationships, 7, 147-178. doi: $0.1177 / 0265407590072001$ 
Booth, A., Johnson, D., \& Edwards, J. N. (1983). Measuring Martial Instability. Journal of Marriage and the Family, 45, 387-393. doi: 10.2307/351516

Brennan, K. A., Clark, C. L., \& Shaver, P. R. (1998). Self-report measurement of adult romantic attachment: An integrative overview. In J. A. Simpson \& W. S. Rholes (Eds.), Attachment theory and close relationships (pp. 46-76). New York: Guilord Press.

Burdette, A. M., Ellison, C. G., Sherkat, D. E., \& Gore, K. A. (2007). Are there religious variations in marital infidelity? Journal of Family Issues, 28, 1553-1581. doi: 10.1177/0192513x07304269

Cano, A., \& O'Leary, K. D. (2000). Infidelity and separations precipitate major depressive episodes and symptoms of nonspecific depression and anxiety. Journal of Consulting and Clinical Psychology, 68, 774-781. doi: 10.1037/0022-006x.68.5.774

DeWall, C. N., Lambert, N. M., Slotter, E. B., Pond Jr, R. S., Deckman, T., Finkel, E. J., ... \& Fincham, F. D. (2011). So far away from one's partner, yet so close to romantic alternatives: Avoidant attachment, interest in alternatives, and infidelity. Journal of Personality and Social Psychology, 101(6), 13021316. doi: $10.1037 / \mathrm{a} 0025497$

Drigotas, S. M., Safstrom, C. A., \& Gentilia, T. (1999). An investment model prediction of dating infidelity. Journal of Personality and Social Psychology, 77(3), 509-524. doi: 10.1037/0022-3514.77.3.509

Fincham, F. D., \& May, R. W. (2017). Infidelity in romantic relationships. Current Opinion in Psychology, 13, 70-74. doi: 10.1016/j.copsyc.2016.03.008

Finney, S. J., \& DiStefano, C. (2006). Non-normal and categorical data in structural equation modeling. Structural equation modeling: A second course, 10(6), 269-314.

Fish, J. N., Pavkov, T. W., Wetchler, J. L., \& Bercik, J. (2012). Characteristics of those who participate in infidelity: The role of adult attachment and differentiation in extradyadic experiences. The American Journal of Family Therapy, 40(3), 214-229. doi: 10.1080/01926187.2011.601192

Gibson, K. A., Thompson, A. E., \& O'Sullivan, L. F. (2016). Love thy neighbour: Personality traits, relationship quality, and attraction to others as predictors of infidelity among young adults. The Canadian Journal of Human Sexuality, 25(3), 186-198. doi:10.3138/cjhs.253-a2

Glass, S. P., \& Wright, T. L. (1985). Sex differences in type of extramarital involvement and marital dissatisfaction. Sex Roles, 12(9-10), 1101-1120. doi:10.1007/bf00288108 
Gordon, K. C., Baucom, D. H., \& Snyder, D. K. (2005). Treating couples recovering from infidelity: An integrative approach. Journal of Clinical Psychology, 61, 1393-1405. doi: 10.1002/jclp.20189

Hendrick, C., Hendrick, S. S., \& Dicke, A. (1998). The love attitudes scale: Short form. Journal of Social and Personal Relationships, 15(2), 147-159. doi: 10.1177/0265407598152001

Hertlein, K. A., Wetchler, J. L. \& Piercy, F. P. (2005). Infidelity: An Overview. Journal of Couple and Relationship Therapy, 4 , 5-16. doi: 10.1300/J398v04n02_02

Kamenov, Ž. i Jelić, M. (2003). Validacija instrumenta za mjerenje privrženosti u različitim vrstama bliskih odnosa: Modifikacija Brennanova Inventara iskustava u bliskim vezama. Suvremena psihologija, 6, 73-91.

Larson J.M. (2014). Relationship satisfaction, attitudes toward infidelity. Nashville, TN: Trevecca Nazarene University.

Lee, J.A. (1973). The Colors of Love: An Exploration of the Ways of Loving.Ontario: New Press.

Maddox Shaw, A. M., Rhoades, G. K., Allen, E. S., Stanley, S. M., \& Markman, H. J. (2013). Predictors of extradyadic sexual involvement in unmarried opposite-sex relationships. Journal of Sex Research, 50(6), 598-610. doi:10.1080/00224499.2012.666816

Mark, K. P., Janssen, E., \& Milhausen, R. R. (2011). Infidelity in heterosexual couples: Demographic, interpersonal, and personality-related predictors of extradyadic sex. Archives of Sexual Behavior,40(5), 971-982. doi:10.1007/s10508-011-9771-z

Markman, H. J. (2005). The prevention of extramarital involvement: Steps toward "affair proofing" marriage. Clinical Psychology: Science and Practice, 12(2), 134-138. doi:10.1093/clipsy.bpi016

Mattingly, B. A., Clark, E. M., Weidler, D. J., Bullock, M., Hackathorn, J., \& Blankmeyer, K. (2011). Sociosexual orientation, commitment, and infidelity: A mediation analysis. The Journal of Social Psychology, 151(3), 222-226. doi:10.1080/00224540903536162

McAnulty, R. D., \& Brineman, J. M. (2007). Infidelity in dating relationships. Annual Review of Sex Research, 18(1), 94-114.

Moller, N., \& Vossler, A. (2014). Defining infidelity in research and couple counseling: A qualitative study. Journal of Sex \& Marital Therapy, 487497. doi: 10.1080/0092623X.2014.931314 
Preveti, D., \& Amato, P. R. (2004). Is infidelity a cause or consequence of poor marital quality? Journal of Social and Personal Relationships, 21, 217230. doi:10.1177/0265407504041384

Russell, V. M., Baker, L. R., \& McNulty, J. K. (2013). Attachment insecurity and infidelity in marriage: Do studies of dating relationships really inform us about marriage?. Journal of Family Psychology,27(2), 242. doi: $10.1037 / \mathrm{a} 0032118$

Shackelford, T. K., Besser, A., \& Goetz, A. T. (2008). Personality, marital satisfaction, and probability of marital infidelity. Individual Differences Research, 6(1), 13-25.

Shackelford, T. K., LeBlanc, G. J., \& Drass, E. (2000). Emotional reactions to infidelity. Cognition and Emotion, 14, 643-659. doi:10.1080/02699930050117657

Spanier, G. B. (1976). Measuring dyadic adjustment: New scales for assessing the quality of marriage and similar dyads. Journal of Marriage and the Family, 2, 15-28. doi: $10.2307 / 350547$

Thompson, A. P. (1983). Extramarital sex: A review of the research literature. Journal of Sex Research, 19(1), 1-22. doi:10.1080/00224498309551166

Træen, B., Holmen, K., \& Stigum, H. (2007). Extradyadic sexual relationships in Norway. Archives of Sexual Behavior, 36(1), 55-65. doi:10.1007/s10508006-9080-0

Treas, J., \& Giesen, D. (2000). Sexual infidelity among married and cohabitating America. Journal of Marriage and the Family, 62, 48-60. doi:10.1111/j.1741-3737.2000.00048.x

Turliuc, M. N., \& Scutaru, E. L. (2013). A semi-model of predictive factors for mixed infidelity. Annals of AII Cuza University. Psychology Series, 22(2), $35-49$.

Vandello, J. A., \& Cohen, D. (2003). Male Honor and female fidelity: Implicit cultural scripts that perpetuate domestic violence. Journal of Personality and Social Psychology, 84, 997-1010. doi:10.1037/0022-3514.84.5.997

Whisman, M. A., \& Snyder, D. K. (2007). Sexual infidelity in a national survey of American women: Differences in prevalence and correlates as a function of method of assessment. Journal of Family Psychology, 21(2), 147-154. doi:10.1037/0893-3200.21.2.147 
Wiederman, M. W. (1997). Extramarital sex: Prevalence and correlates in a national survey. Journal of Sex Research, 34, 167-174. doi:10.1080/00224499709551881

Zare, B. (2011). Review of studies on infidelity. International Proceedings of Economics Development and Research, 19, 182-186. doi:10.7763/IPEDR 